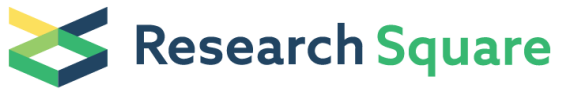 \\ Preprints are preliminary reports that have not undergone peer review. \\ They should not be considered conclusive, used to inform clinical practice, or referenced by the media as validated information.
}

\section{Ischemic Stroke: An Emerging Complication of COVID-19}

\author{
Geoffroy Hautecloque \\ Hopitaux Civils de Colmar \\ Francois sellal \\ Hopitaux Civils de Colmar \\ Simon Gravier \\ Hopitaux Civils de Colmar \\ Thomas Bonijoly \\ Hopitaux Civils de Colmar \\ Celine lltis \\ Hopitaux Civils de Colmar \\ Pierre Anthony \\ Hopitaux Civils de Colmar \\ Catherine Renglewicz \\ Hopitaux Civils de Colmar \\ Marie-Hélène Arentz-Dugay \\ Hopitaux Civils de Colmar \\ Mahsa Mohseni-Zadeh \\ Hopitaux Civils de Colmar \\ Martin Martinot (D martin.martinot@ch-colmar.fr) \\ Hopitaux Civils de Colmar https://orcid.org/0000-0003-4524-9064
}

\section{Research article}

Keywords: Ischemic stroke, Covid-19, SARS-Cov-2, cardioembolism

Posted Date: July 8th, 2020

DOI: https://doi.org/10.21203/rs.3.rs-35504/v1

License: (9) (7) This work is licensed under a Creative Commons Attribution 4.0 International License. Read Full License 


\section{Abstract}

\section{Background}

Covid-19 affects mainly the respiratory tract but extra-pulmonary manifestations have been reported including neurologic disorders. Stroke is uncommonly reported in hospitalized patients with Covid-19. To assess the real burden of stroke during Covid-19 we performed a single-center review of stroke among patients with laboratory-confirmed Covid-19.

\section{Methods}

We retrospectively searched Colmar Hospital's database for all the patients with laboratory confirmed Covid-19 who had a stroke between March 3 and April $21,2020$.

\section{Results}

We report seven cases (mean age 73 years) of ischemic stroke among 674 patients hospitalized for laboratory-confirmed coronavirus disease 2019 (Covid19). Three patients experienced a stroke during hospitalization, and four patients were tested positive $24 \mathrm{~h}$ after their admission for stroke. Patients with stroke experienced a predominance of cardioembolic mechanisms, high levels of inflammatory markers, and procoagulative states.

\section{Conclusion}

Ischemic stroke is a serious threat in patients with Covid-19, mainly due to an embolic mechanism and cardiologists and neurologists must collaborate in management and prevention of stroke during the Covid-19 pandemic

\section{Background}

Coronavirus disease 2019 (Covid-19) is a polymorph disease caused by the new severe acute respiratory syndrome coronavirus (SARS-Cov-2), which emerged in China in December 2019 and rapidly spread worldwide. Covid-19 affects mainly the respiratory tract with clinical forms ranging from slightly symptomatic upper respiratory tract infection to systemic acute respiratory syndrome [1] Extrapulmonary manifestations that have been reported include neurologic disorders, such as viral meningitis, encephalitis, postinfectious acute disseminated encephalomyelitis, postinfectious brainstem encephalomyelitis, GuillainBarré syndrome, myositis, and acute necrotizing hemorrhagic encephalopathy [2] as well as thrombotic disorders, mainly deep vein thrombosis, pulmonary embolism, or acute coronary syndrome [3] Stroke is uncommonly reported in hospitalized patients with Covid-19, and it occurs primarily in the most severely ill patients [4-6]. We performed a single-center review of stroke among patients with laboratory-confirmed Covid-19 who were hospitalized between March 3, 2020, and April 21, 2020, in Colmar Hospital, Colmar, France. We describe the initial presentation of these cases and discuss the relation between SARS-Cov-2 infection and the need to adapt neurovascular circuits during the Covid-19 pandemic.

\section{Methods}

We retrospectively analyzed stroke among patients in Colmar Hospital with Covid-19 between March 3 and April 21, 2020. Colmar Hospital is a 1000-bed facility in northeastern France, a region in which a major outbreak of Covid-19 occurred during this period. .A laboratory confirmed Covid-19 by a positive result of real-time reverse transcriptase polymerase chain reaction (PCR) for SARS-Cov-2 (nasopharyngeal swab, endotracheal aspirate, or sputum). We searched Colmar Hospital's database for all the patients with Covid- 19 who had a stroke. The study was approved by the ethical committees of the odontology and pharmacy faculties and hospitals.

\section{Results}

Between March 3 and April 21, 2020, 674 patients were hospitalized with PCR-confirmed Covid-19. We identified seven patients (1,04\%), five men and two women, who developed an ischemic stroke during this period. The patients' mean age was 73 years (range, 59 to 86 years), and mean body mass index (BMI) was $26.9 \mathrm{~kg} / \mathrm{m}^{2}$. Stroke occurred a mean of 14.5 days after the onset of Covid-19 (range, 4 to 25 days) in four patients for whom a delay could be determined (patients 1 to 4). Four patients (patients 4 to 7) were admitted for stroke. None of these patients was hospitalized in the intensive care unit (ICU). All patients had comorbidities: hypertension in 6, diabetes in two, and atrial fibrillation in one (patient 5). Two patients were treated with angiotensin-converting enzyme blockers. The mean C-reactive protein (CRP) level was $42.6 \mathrm{mg} / \mathrm{l}$ (range, 4 to $105 \mathrm{mg} / \mathrm{l}$ ). Patients' characteristics are summarized in Table 1.

Suspected causes of ischemic stroke were cardioembolism in four patients (patients 2, 3, 4, and 5) and atheromatosis in two patients (patients 1 and 6). Two patients (patients 3 and 5) had atrial fibrillation; one (patient 2) exhibited bursts of atrial tachycardia without arrhythmia on electrocardiographic monitoring and had strokes affecting multiple vascular territories; and one (patient 4) had myocardial infarction and multiple strokes. In one patient (patient 7), we found no cause, but he had potential thrombophilia. Among the patients with cardioembolic strokes, three (patients 2, 3, and 4) had multiple infarcts. In all three, diffusion-weighted and apparent diffusion coefficient magnetic resonance imaging demonstrated at least one small acute ischemic stroke (Figure 1). All other patients had a single subacute ischemic stroke

Thromboembolic events have been reported in patients with Covid-19 [3] especially in ICUs. Klok et al. reported thrombotic events in 56 (31\%) of 182 patients with a SARS-Cov-2 infection; the majority of events were acute pulmonary embolisms, deep vein thromboses, and three cases of arterial stroke all of which that occurred despite anticoagulant prophylaxis [4]. Our patients were not in an ICU; stroke was diagnosed at admission in four patients and during hospitalization for Covid-19 in three. 


\section{Discussion}

Preexisting cardiovascular conditions are risk factors for severe Covid-19 and death; however, Covid-19 may also facilitate cardiovascular disturbances such as arrhythmias, myocardial dysfunction, and thrombosis [7, 8]. The mechanisms leading to stroke during Covid-19 may be multiple in such patients with previous cardiovascular conditions, including classical mechanisms of stroke (i.e., arrhythmias, emboli from atherosclerosis plaque) and specific conditions (high levels of inflammatory biomarkers and procoagulability states caused by cytokine storm [9]). In our patients, cardioembolic mechanisms were the main causes of ischemic stroke in $57 \%$, which is a much higher incidence than the literature indicates (20\% to $25 \%$ ) [10, 11$]$; Covid-19 played a direct role in cardiac dysfunction in patient 4 (myocardial infarction). Two patients had marked carotid atherosclerosis, six patients were older than 65 years, and all seven had cardiovascular risk factors. These potential risk factors were noted by Li et al. in their article on acute cerebrovascular disease after Covid-19. Of interest is that the mean age of the patients with ischemic stroke in Li et al.'s study (71 years) was quite similar to ours (73 years) [5] though stroke have been reported in younger patients with Covid-19 [12].

Our patients had a hypercoagulable state; the mean CRP level was $42.5 \mathrm{mg} / \mathrm{l}$ at the time of stroke. Similarities in inflammatory levels were noted by Li et al.: The median CRP level in their patients was $51.1 \mathrm{mg} / \mathrm{l}$, and stroke occurred a mean of 12 days after Covid-19 hospitalization [5] (14 days in our study), which corresponded to the phase in which inflammatory processes are more active because of immunologic dysfunction. It may be hypothesized that sepsis and the inflammatory syndrome are related and can be marked in Covid-19, especially in serious cases, and the resulting coagulation disorders are of great concern in ischemic stroke related to Covid-19 [13-15].

Among the 674 patients hospitalized during this period for laboratory-confirmed Covid-19, the prevalence of ischemic stroke was $1.04 \%$. This rate is lower than those previously reported $[5,6]$ but it is possible that some mildly symptomatic strokes might have escaped scrutiny especially in the ICU. Helms et al. showed that of 13 patients admitted to an ICU for acute respiratory distress syndrome, three (23\%) suffered a stroke, and of those patients, two had a small acute ischemic stroke and had no symptoms[16] Moreover, during the March and April overflow period, a high number of patients in the ICU had to be transferred to external facilities, and their data were therefore not analyzed. Finally, we studied only cases of laboratory-confirmed Covid-19 and thus underestimated all possible cases, inasmuch as real-time reverse transcriptase PCR sensitivity was approximately $70 \%$.

Of the four patients in this study admitted to a neurovascular unit for stroke, two underwent thrombolysis and thrombectomy. Admission to the neurovascular unit and the endovascular manipulation were performed without adapted protective personal equipment; within 1 day of admission, all four were found to have Covid-19. Therefore, screening for SARS-Cov-2 should be conducted in cases of stroke [17, 18]. Moreover, three patients with secondary Covid-19 received anticoagulant prophylactic treatment, and one patient with atrial fibrillation received rivaroxaban treatment. These cases suggest the need for systematic and adapted prophylactic or curative anticoagulation in patients with Covid-19 [19]. Prospective studies are necessary to determine the real burden of strokes during Covid-19, to minimize the risk to health care professionals in charge of patients with stroke, and to define the best prophylactic and therapeutic treatment to optimize these patients' neurologic outcomes.

\section{Conclusion}

Our case series investigate the risk for ischemic stroke in patients with Covid-19 on a large scale. In contrast to previous preliminary reports, we found that strokes are not the hallmark of severe forms of Covid-19 in patients requiring admission to an ICU. They occur in patients with multiple comorbidities, but we found a predominance of cardioembolic mechanisms, high levels of inflammatory markers, and procoagulative states in infected patients. Ischemic stroke is a serious threat in patients with Covid-19, and cardiologists and neurologists must collaborate in management and prevention of stroke during the Covid-19 pandemic.

\section{Abbreviations}

BMI: body mass index; Covid-19 : Coronavirus disease 2019; CRP: C-reactive protein; ICU : intensive care unit; PCR : polymerase chain reaction; SARS-Cov-2: severe acute respiratory syndrome coronavirus

\section{Declarations}

\section{Acknowledgements}

The authors thank all the healthcare professionals who took care of the patients infected with SARS-Cov-2 at the Civil Hospitals of Colmar.

\section{Authors' contribution}

GH, FS and MM conceived and designed the study, analysed and interpreted the data, drafted/revised the manuscript. GH, FS, SG, TB, Cl, PA, CR, M-HA-D, MMZ and $\mathrm{MM}$ have collected the data, read and approved the manuscript.

\section{Funding}

None

\section{Availability of data and materials.}

All data generated or analyzed during this study are included in this published article. 
Ethics approval and consent to participate

The study was approved by the ethical committees of the odontology and pharmacy faculties and hospitals. Ethics committee of the University Hospital of Strasbourg

\section{Consent for publication}

Not applicable

\section{Competing interests}

The authors declare that they have no competing interests.

\section{References}

1. Guan WJ, Ni ZY, Hu Y, Liang WH, Ou CQ, He JX et al. Clinical Characteristics of Coronavirus Disease 2019 in China. N Engl J Med. 2020. doi:10.1056/NEJMoa2002032.

2. Nath A. Neurologic complications of coronavirus infections. Neurology. 2020. doi:10.1212/WNL.0000000000009455.

3. Bikdeli B, Madhavan MV, Jimenez D, Chuich T, Dreyfus I, Driggin E et al. COVID-19 and Thrombotic or Thromboembolic Disease: Implications for Prevention, Antithrombotic Therapy, and Follow-up. J Am Coll Cardiol. 2020. doi:10.1016/j.jacc.2020.04.031.

4. Klok FA, Kruip M, van der Meer NJM, Arbous MS, Gommers D, Kant KM et al. Incidence of thrombotic complications in critically ill ICU patients with COVID19. Thromb Res. 2020. doi:10.1016/j.thromres.2020.04.013.

5. Li Y, Wang M, Zhou Y, Chang J, Xian Y, Mao L et al. Acute Cerebrovascular Disease Following COVID-19: A Single Center, Retrospective, Observational Study. (htpps://papers.ssrn.com/sol3/papers.cfm?abstract_id=3550025)(preprint). 2020(March 13). doi:http://dx.doi.org/10.2139/ssrn.3550025

6. Mao L, Jin H, Wang M, Hu Y, Chen S, He Q et al. Neurologic Manifestations of Hospitalized Patients With Coronavirus Disease 2019 in Wuhan, China. JAMA Neurol. 2020. doi:10.1001/jamaneurol.2020.1127.

7. Driggin E, Madhavan MV, Bikdeli B, Chuich T, Laracy J, Bondi-Zoccai G et al. Cardiovascular Considerations for Patients, Health Care Workers, and Health Systems During the Coronavirus Disease 2019 (COVID-19) Pandemic. J Am Coll Cardiol. 2020. doi:10.1016/j.jacc.2020.03.031.

8. Ruan Q, Yang K, Wang W, Jiang L, Song J. Clinical predictors of mortality due to COVID-19 based on an analysis of data of 150 patients from Wuhan, China. Intensive Care Med. 2020. doi:10.1007/s00134-020-05991-x.

9. Qin C, Zhou L, Hu Z, Zhang S, Yang S, Tao Y et al. Dysregulation of immune response in patients with COVID-19 in Wuhan, China. Clin Infect Dis. 2020. doi:10.1093/cid/ciaa248.

10. Caprio FZ, Sorond FA. Cerebrovascular Disease: Primary and Secondary Stroke Prevention. Med Clin North Am. 2019;103(2):295-308. doi:10.1016/j.mcna.2018.10.001.

11. Ferro JM. Cardioembolic stroke: an update. Lancet Neurol. 2003;2(3):177-88. doi:10.1016/s1474-4422(03)00324-7.

12. Oxley TJ, Mocco J, Majidi S, Kellner CP, Shoirah H, Singh IP et al. Large-Vessel Stroke as a Presenting Feature of Covid-19 in the Young. N Engl J Med. 2020. doi:10.1056/NEJMc2009787.

13. Liu PP, Blet A, Smyth D, Li H. The Science Underlying COVID-19: Implications for the Cardiovascular System. Circulation. 2020. doi:10.1161/CIRCULATIONAHA.120.047549.

14. Marone EM, Rinaldi LF. Upsurge of deep venous thrombosis in patients affected by COVID-19: preliminary data and possible explanations. J Vasc Surg Venous Lymphat Disord. 2020. doi:10.1016/j.jvsv.2020.04.004.

15. Giannis D, Ziogas IA, Gianni P. Coagulation disorders in coronavirus infected patients: COVID-19, SARS-CoV-1, MERS-CoV and lessons from the past. J Clin Virol. 2020;127:104362. doi:10.1016/j.jcv.2020.104362.

16. Helms J, Kremer S, Merdji H, Clere-Jehl R, Schenck M, Kummerlen C et al. Neurologic Features in Severe SARS-CoV-2 Infection. N Engl J Med. 2020. doi:10.1056/NEJMc2008597.

17. Fiorella D, Fargen KM, Leslie-Mazwi TM, Levitt M, Probst S, Bergese S et al. Neurointervention for emergent large vessel occlusion during the covid-19 pandemic. J Neurointerv Surg. 2020. doi:10.1136/neurintsurg-2020-016117.

18. Baracchini C, Pieroni A, Viaro F, Cianci V, Cattelan AM, Tiberio I et al. Acute stroke management pathway during Coronavirus-19 pandemic. Neurol Sci. 2020. doi:10.1007/s10072-020-04375-9.

19. Marietta M, Ageno W, Artoni A, De Candia E, Gresele P, Marchetti M et al. COVID-19 and haemostasis: a position paper from Italian Society on Thrombosis and Haemostasis (SISET). Blood Transfus. 2020. doi:10.2450/2020.0083-20.

\section{Tables}


Table 1

Medical and biological characteristics of patients. *CRP levels at peak and time of stroke. BMI: body mass index, CRP: C-reactive protein, ND: no data, NIHSS: National Institutes of Health Stroke Scale; PCR: polymerase chain reaction.

\begin{tabular}{|c|c|c|c|c|c|c|c|}
\hline & Patient 1 & Patient 2 & Patient 3 & Patient 4 & Patient 5 & Patient 6 & Patient 7 \\
\hline $\begin{array}{l}\text { Sex and Age } \\
\text { (range years) }\end{array}$ & $F, 85-90$ years & M, 75-80years & M, 70-75years & M, 65-70years & F, 70-75years & M, 75-80years & M, 55-60years \\
\hline \multirow{8}{*}{$\begin{array}{l}\text { Past Medical } \\
\text { History }\end{array}$} & Hypertension & Hypertension & Dyslipidemia & Hypertension & Hypertension & Hypertension & Hypertension \\
\hline & $\begin{array}{l}\text { Valvular } \\
\text { cardiopathy }\end{array}$ & Psoriasis & Asthma & $\begin{array}{l}\text { Mild renal } \\
\text { chronic } \\
\text { insufficiency }\end{array}$ & $\begin{array}{l}\text { Paroxysmal atrial } \\
\text { fibrillation }\end{array}$ & Polyps & \\
\hline & $\begin{array}{l}\text { Deep vein } \\
\text { thrombosis }\end{array}$ & Hypothyroidism & & Type 2 diabetes & Active smoking & $\begin{array}{l}\text { Past history of } \\
\text { smoking }\end{array}$ & \\
\hline & & & & & Ovarian neoplasia & & \\
\hline & $\begin{array}{l}\text { Nonsecreting } \\
\text { suprarenal } \\
\text { tumor }\end{array}$ & & & Dyslipidemia & & $\begin{array}{l}\text { Type } 2 \\
\text { diabestes }\end{array}$ & \\
\hline & & & & Gout & & & \\
\hline & & & & $\begin{array}{l}\text { Alcohol } \\
\text { consumption }\end{array}$ & & & \\
\hline & & & & $\begin{array}{l}\text { Central retinal } \\
\text { artery occlusion }\end{array}$ & & & \\
\hline BMI $\left(\mathrm{kg} / \mathrm{m}^{2}\right)$ & 33.2 & 21.3 & 30.4 & 24.4 & 28.2 & 24.0 & 36.3 \\
\hline \multirow[t]{6}{*}{ Treatment } & Losartan & Lercanidipine & Rivaroxaban & Losartan & Nebivolol & Metformin & Lercanidipine \\
\hline & Aspirin & Levothyroxine & Bisoprolol & Metformin & & Insulin & Esomeprazole \\
\hline & Atorvastatin & & Atorvastatin & Aspirin & & Nebivolol & \\
\hline & & & & Amlodipine & & Lorazepam & \\
\hline & & & & Febuxostat & & & \\
\hline & & & & Rosuvastatin & & & \\
\hline Anticoagulation & $\begin{array}{l}\text { Prophylactic } \\
\text { (Enoxaparine } \\
4000 \text { UI) }\end{array}$ & $\begin{array}{l}\text { Prophylactic } \\
\text { (Enoxaparine } \\
4000 \text { UI) }\end{array}$ & $\begin{array}{l}\text { Curative } \\
\text { (Rivaroxaban } \\
\text { 20mg) }\end{array}$ & - & - & - & - \\
\hline $\begin{array}{l}\text { Time between } \\
\text { Covid-19 Onset } \\
\text { and Stroke }\end{array}$ & 15 days & 14 days & 25 days & 4 days & Unknown & Unknown & Unknown \\
\hline $\begin{array}{l}\text { D-Dimers } \\
\text { (ng/ml) }\end{array}$ & 9276 & ND & 993 & 7026 & ND & 560 & 2868 \\
\hline $\begin{array}{l}\text { Prothrombin } \\
\text { (\%) }\end{array}$ & 104 & 113 & ND & 82 & 83 & $>120$ & 110 \\
\hline $\begin{array}{l}\text { Fibrinogen } \\
\text { Levels (g/l) }\end{array}$ & 5.35 & 7.81 & 6.05 & 10.5 & ND & 5.2 & 4.87 \\
\hline $\begin{array}{l}\text { CRP Level } \\
\text { (mg/L) (Time } \\
\text { of Stroke)* }\end{array}$ & 9 & 53 & 30 & 75 & 105 & 22 & 4 \\
\hline \multirow[t]{2}{*}{$\begin{array}{l}\text { Clinical } \\
\text { Manifestations } \\
\text { of Stroke }\end{array}$} & $\begin{array}{l}\text { Left } \\
\text { hemiplegia, } \\
\text { left } \\
\text { hypoesthesia }\end{array}$ & $\begin{array}{l}\text { Dysarthria, right } \\
\text { proportional } \\
\text { hemiparesis }\end{array}$ & $\begin{array}{l}\text { Temporospatial } \\
\text { disorientation, } \\
\text { incoherent } \\
\text { speech }\end{array}$ & $\begin{array}{l}\text { Left upper limb } \\
\text { paresis, left } \\
\text { facial paresis, } \\
\text { dysarthria }\end{array}$ & $\begin{array}{l}\text { Left facial paresis, } \\
\text { left } \\
\text { hemihypoesthesia, } \\
\text { dysarthria, } \\
\text { heminegligence }\end{array}$ & $\begin{array}{l}\text { Transient } \\
\text { aphasia }\end{array}$ & $\begin{array}{l}\text { Left hemiplegia, } \\
\text { Left } \\
\text { hemihypoesthesia }\end{array}$ \\
\hline & $\begin{array}{l}\text { NIHSS score: } \\
8\end{array}$ & NIHSS score: 6 & NIHSS score: 2 & NIHSS score: 15 & NIHSS score: 3 & NIHSS score : 0 & NIHSS score: 13 \\
\hline Location & $\begin{array}{l}\text { Right middle } \\
\text { cerebral artery }\end{array}$ & $\begin{array}{l}\text { Left middle } \\
\text { cerebral artery } \\
\text { Right middle } \\
\text { cerebral artery } \\
\text { (one small } \\
\text { cortical infarct) }\end{array}$ & $\begin{array}{l}\text { Right middle } \\
\text { cerebral artery } \\
\text { Left middle } \\
\text { cerebral artery } \\
\text { (small cortical } \\
\text { infarct) } \\
\text { Left cerebellar } \\
\text { artery (one } \\
\text { small infarct) }\end{array}$ & $\begin{array}{l}\text { Right middle } \\
\text { cerebral artery } \\
\text { Left middle } \\
\text { cerebral artery } \\
\text { (one small } \\
\text { cortical infarct) }\end{array}$ & $\begin{array}{l}\text { Right middle } \\
\text { cerebral artery }\end{array}$ & $\begin{array}{l}\text { White matter } \\
\text { hyperintensities }\end{array}$ & $\begin{array}{l}\text { Right middle } \\
\text { cerebral artery }\end{array}$ \\
\hline
\end{tabular}

Mechanism Probably Cardioembolism Cardioembolism Possible Cardioembolism Probably Unknown;


atherosclerotic (50\% bilateral carotid artery stenosis) (multiple bursts of atrial tachycardia) (atrial fibrillation discovered at Covid-19 onset) cardioembolism (multiple strokes in different

vascular

territories,

myocardial

infarction) but

presence of

atherosclerosis

(multiple

stenoses, $\geq 60 \%$

in cervical

vessels) and

positive

circulating

anticoagulant

with protein $\mathrm{S}$

deficiency (one

determination ) (paroxysmal atrial arteriosclerosis fibrillation) possibly protein S

deficiency,

circulating anticoagulant

(one

determination)

\section{Figures}

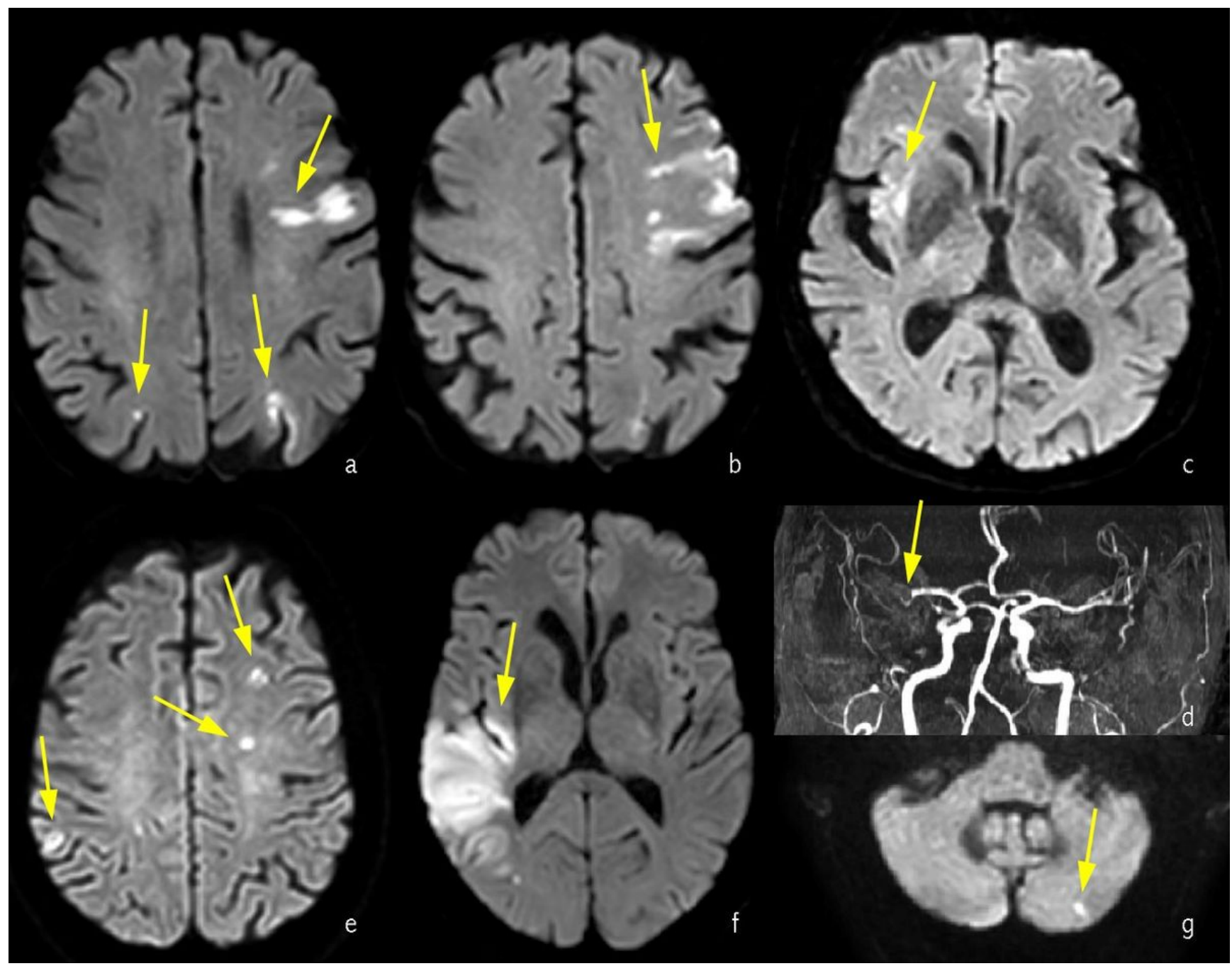

Figure 1

Magnetic Resonance Imaging, Axial Slices. Cardioembolic strokes. First row: Images a,b (patient 2). Diffusion weighted images showing multiple bilateral ischemic lesions (arrows). Images c,d (patient 5). Recent right insular infarct (c). Thrombus in the right middle cerebral artery (d). Lower row: Images e,f,g (patient 3). Diffusion weighted images. Multiple recent infarcts in different vascular territories. 